\title{
Application of the Snowball Sample in the diagnostic based on factors that affect the productivity of Cherimoya production in MSEs: A case of study of Callahuanca and San Mateo de Otao, Peru
}

\author{
Dr. Fernando Sotelo \\ School of Industrial Engineering, \\ Universidad Peruana de Ciencias Aplicadas, Lima, Perú \\ Ms. Andrea Molina \\ School of Industrial Engineering, \\ Universidad Peruana de Ciencias Aplicadas, Lima, Perú \\ Ms. Katty Rojas \\ School of Industrial Engineering, \\ Universidad Peruana de Ciencias Aplicadas, Lima, Perú
}

\begin{abstract}
It is evident that economic poverty is one of the problems presented by underdeveloped countries, and that their reduction is related to the increase in productivity in MSEs, given the high impact they have represented over time. Many entities have identified the importance of agriculture in the economic sector of the country. Therefore, a diagnosis is necessary in the area. The purpose of this diagnosis is to have a reference of the environment from the general point of view, in which all the interactions, descriptions, particularities and existing processes can be observed. In this first stage of the diagnosis, it is carried out using a non-probabilistic sampling, which is a common method in the investigation. One of the many methods used for identifying diagnosis is the snowball sampling that allows finding the diagnosis of hidden populations where there is no way to know all the characteristics of a population. The benefit of using this type of sampling is that a single initial informant can put the researcher in contact with other sources. Further, based on the results obtained, it was identified that the causes of the problem of the Cherimoya sector were associated to 3 critical processes that reflected the non-productivity of this sector: process of planning management and production control, process of logistic management and process of quality management.
\end{abstract}

\section{INTRODUCTION}

According to the data collected from INEI (2017), during 2017 the annual GDP registered a percentage change of only $2.5 \%$ compared to $4 \%$ of the past year, which is explained by the decrease of extraction activities (9.1\% to 3\%). In this decrease, the agricultural sector varied by $-4 \%$ during the first quarter of 2017 compared to the last quarter of 2016. Diario Gestión (2017) justifies that this low growth was due to the effects of the "Niño Costero": the destruction of 2,629 km. of roads, the loss of 198,000 homes and the difficulties they had in the logistics and communications of extractive activities.

The percentage variation of the last years of the agricultural sector that contributes to GDP has been $0.2 \%, 1.3 \%, 2.2 \%$ and 2.6\%, 2.2\% in 2014, 2015, 2016 and 2017 respectively. MSEs of the sector of Agriculture, hunting and forestry are made up of a total of 24,525 companies, of which $90.3 \%$ are microenterprises, while $7.8 \%$ are small com'vvcpanies. That means that in 
this agricultural sector MSEs manage to reach an approximate participation of $98 \%$. One of the products of this agricultural sector is the cherimoya, which has a stable production over the years.

\section{LITERATURE REVIEW}

Samuel Morley (2017) affirms, economic poverty is one of the problems that occurs mainly in underdeveloped countries. Within these countries is Peru, which is one of the Latin American countries that has presented major economic problems for decades. However, during 2004 and 2012, Peru found itself in a period where its economy improved, which was associated with the reduction of poverty in the country. This was due to the fact that the per capita income had an increase of more than 5.5\% per year, and this scenario brought about that the total poverty is reduced. This idea justifies what Vladislav Maksimov (2017) indicates, who comments that, among the main solutions to reduce poverty in underdeveloped countries, it is necessary to increase the level of income of workers.

Additionally, Gazi Salah and others (2017) affirm that there is a relationship between financial development, economic growth and the reduction of poverty in a country. This was observed in the study carried out by these authors in Bangladesh, where the financial sector improved the financial intermediation process through the adoption of a series of legal, political and institutional restructurings. As a result, GDP grew at an average annual rate of 5.8\% during 2000-2009 and reflected a decrease in poverty. This idea is reinforced by Goedele Van Den and Miet Maertens (2017) in an investigation carried out in Senegal River Delta - Africa, between 2006 and 2013, where it is shown that the average income of a house grew by $4.3 \%$ and that reflected a reduction in poverty of $29.5 \%$ and $4.2 \%$ in inequality.

On the other hand, a study conducted during the years 2002-2011 in Peru by Gustavo Canavire-Bacarreza and Marcos Robles (2017), reveals that the population remained 6 of the 10 years in poverty, while the probability of leaving it It is much lower. For this reason, the authors Magdalena Kopelko and Malcom Abbott (2017) affirm that there is a strong relationship between the economic growth of an underdeveloped country and the productivity of the companies that make it up, due to the great impact it can generate. In addition, they indicate that companies use many means to become productive as technological tools and better use of their resources.

This idea, too, is supported by Chad Syverson (2017), who points out that the main indicator of economic growth for a company and for a business sector is productivity. In that sense, its measurement is relevant to properly determine the improvement of productivity, and thus avoid an incorrect measurement of its growth. For this reason, Jurgen Antony and others (2017) say that countries with high levels of productivity and high technology should invest their resources to innovation, while countries with low levels of productivity should direct their resources to imitate and standardize the market in which they develop to achieve economic growth.

According to the authors Ludovica Savlovschi and Nicoleta Robu (2011), the vast majority of countries have more than $99 \%$ of their companies classified as MSEs, which have a great influence on the GDP of each country.

For Sonu Garg and Parul Agarwal (2017), the MSEs have a different meaning depending on the country, which is distinguished by the number of employees, capital investment, annual turnover and the amount of total assets in the company. For example, in their study they affirm that India has micro, small and medium enterprises that represent $37 \%$ of the GDP and $90 \%$ of 
the total of companies in different economies. This means that they are part of an important segment that symbolizes the growth engine in the economy of this country.

In addition, according to Thi Hong Van Hoang and Others (2018), they indicate that the set of micro-enterprises that a country can have is a source of progress, since these as a whole boost the economy by consuming raw materials prepared as inputs for their products. , its demand power of intermediate goods is also recognized.

The contribution to GDP and the percentage represented by the MSEs is also replicated in a study conducted by Muhammad Mahboob Ali and others (2017) in Bangladesh, Thailand and the Philippines, which indicates that the MSEs represent $99 \%$ of the total of private companies, approximately, and its participation in the GDP varies between $28 \%$ and $30 \%$. According to the Ministry of Production of Peru (2015), in the Industrial Statistical Yearbook - Mipyme and Internal Trade 2015, within the business sector, Peruvian micro-enterprises represent 95\%, equivalent to $1,607,305$ entities, while Small businesses represent only $4.3 \%$. These figures show that the MSEs have a high percentage of participation in the entire economic sector of Peru.

Muhammad Mahboob Ali and others (2017) affirm that small and medium enterprises generate job opportunities, create wealth, promote modernization and contribute with technological changes.

However, they indicate that job creation and innovation are necessary for the development of the economy, as is the case in Asia, where MEPs represent 38\% of GDP. Jaroslav Belás and others (2015), also, maintain that, for the countries of low development, the micro and small organizations are elements of economic stability that generate employment, and in that way they increase the income of the employees, improving their living conditions.

According to Eshetu and Ketema (2013) they indicate that micro and small companies are considered important vehicles to face the challenges of the problems faced by underdeveloped countries, such as: high unemployment rates, low economic growth and inequity in the country.

In Peru, according to the last report published by INEI (2017) on the employability rate in Peru, Peruvian MSEs employ $70.2 \%$ of the economically active population of Peru. Therefore, the development of full employment in the MSEs will directly impact the GDP. This is the case of the Government of the Federal Democratic Republic of Ethiopia, where Haftom Haile Abay and others (2014) carry out a study in which it is indicated that MSEs are an important force for generating employment and a more equitable distribution of income, for thus be able to stimulate the economic development of this country.

On the other hand, John W. Mellora and Sohail J. Malikb (2016) carry out a study that reveals that in low and middle-income countries, where the economic reality is based on whether there is a rapid growth of agricultural production and increase the income of small commercial farmers would represent a high impact on their economy, in such a way that it would be possible to reduce rural poverty.

This premise is also supported by Atya Nur Aisha and others (2016), who indicate that the development of the agricultural sector is a way to boost economic growth, due to the predominance of activities related to agriculture. Likewise, Marcos Ivanic and Will Martin 
(2017), indicates that in poor countries the increase in agricultural productivity has a high impact on the reduction of poverty, and that it has been shown that poverty reduction impacts more in rural areas than in urban areas. This justifies the point made by Satis Devkota and Mukti Upadhyay (2013), who indicate that people who work in agriculture tend to have lower incomes, which is consistent with the fact that poverty is concentrated in rural areas.

From this statement, it is important to understand the participation of the agricultural sector within our country. Within the report "MSEs by business stratum" presented by SUNAT (2015), are the MSEs of the "Agriculture, hunting and forestry" sector, which are made up of a total of 24525 companies, of which $90.3 \%$ are microenterprises, while $7.8 \%$ are small businesses. That is to say that, in this sector, the MSEs manage to reach an approximate participation of $98 \%$.

Rendering to the importance of peruvian MSEs has in this sector, it is decided to make a diagnosis of the area. Yter Vallejos (2008), defines that the diagnosis is the first phase to identify the nature of a problematic situation. The purpose of the diagnosis is to have a reference of the environment from the point of view of the whole, in which you can observe all the relationships interactions, descriptions, peculiarities and existing processes.

According to Lisa given (2008), it indicates that, in this first stage of diagnosis, it is done using a non-probabilistic sampling, which is a common method in the investigation. Unlike probability sampling, where each participant has the same probability of being selected, participants selected using the non-probabilistic sampling technique are chosen because they meet the preestablished criteria.

Oisín Tansey (2007), indicates that the Convenience Sampling technique implies that the investigator selects the available interviewees, regardless of the characteristics, until the required sample size has been reached. As your title suggests, your main advantage lies in your convenience: There are no strict selection rules and the sample can be drawn in the easiest way for the investigator. However, its main disadvantage derives from the same feature: No selection rules, no way to know which broader population represents the sample group or how the sample may differ from other potential samples

On the other hand, it points out that another method is Quota Sampling, which tries to ensure that certain characteristics are present in the sample in proportion to its distribution in the general population. This method provides the investigator with more certainty regarding the composition of the sample and its relationship with the broader population of interest. However, as with most sampling methods, there are certain drawbacks in this selection method. First, the investigator must know the characteristics of the population in advance, which is not always possible. Second, although the sample is representative of the population on the characteristics of interest, there is no way for the investigator to be sure that it is also representative of other characteristics that may be important, for example, class and ethnicity.

In addition, the author mentions that Snowball sampling is one of the best-known forms of non-probabilistic sampling is the snowball sampling method, which is particularly suitable when the population of interest is not completely visible and when compiling a List of the population poses difficulties for the investigator. The snowball or chain reference sampling method implies identifying an initial set of relevant respondents and then asking to suggest other potential subjects that share similar characteristics or that have relevance in some way for the object of study. The investigator then interviews the second group of subjects and requests that they provide the names of other potential subjects of the interview. The process 
continues until the investigator considers the sample to be large enough for the purposes of the study, or until respondents begin repeating names to the extent that new rounds of nominations are unlikely to throw new Meaningful information. As with random sampling, the Snowball method is not as uncontrolled as your name might suggest. The researcher is very involved in the development and management of the start and the progress of the sample and seeks to ensure that the chain of references remains within the limits that are relevant to the study always.

\section{Success Cases}

Steven W. Purcell and others (2016), conducted an investigation of sea cucumber fishermen. WhatS Authors, point out that the method of diagnosis, was through interviews based on questionnaires of fishermen who had recently harvested sea cucumbers. In each village, an average of five fishermen were found for interviews using the snowball technique and key informants, regardless of fishermen's age, fishing mode, frequency of fishing trips and catches, and in that way, the critical need to improve the income and well-being of fishermen could be identified.

Another case study is the one presented by Shuh-Jen Sheu and Others (2008), who conducted research on Drug Administration in hospitals. The diagnostic method was through a snowball sampling to recruit participants. To this end, a semi-structured questionnaire was used to record types of error, hospital and nursing background, patient consequences, error discovery mechanisms and notification rates. As a result, information was collected from eighty-five nurses, reporting 328 errors in Drug Administration, which most errors occurred in surgical medical rooms, during daytime shifts, by nurses Who work less than two years

\section{Study area}

According to the Superintendencia Nacional de administración aduanera y tributaria (2017), they say that the mypes is showing high significant indexes for the Peruvian economy, due to its high participation in the percentage of the national production.

On the other hand, as indicated in the Industrial Statistical Yearbook, MMSEs and internal trade 2016, officialized by the Ministry of Production, Graph 1 shows that in the entire business sector, micro and small enterprises account for 95.1\%, equivalent to 1,652,071EStas figures show the importance and high participation of MSEs in the country's economic sector.

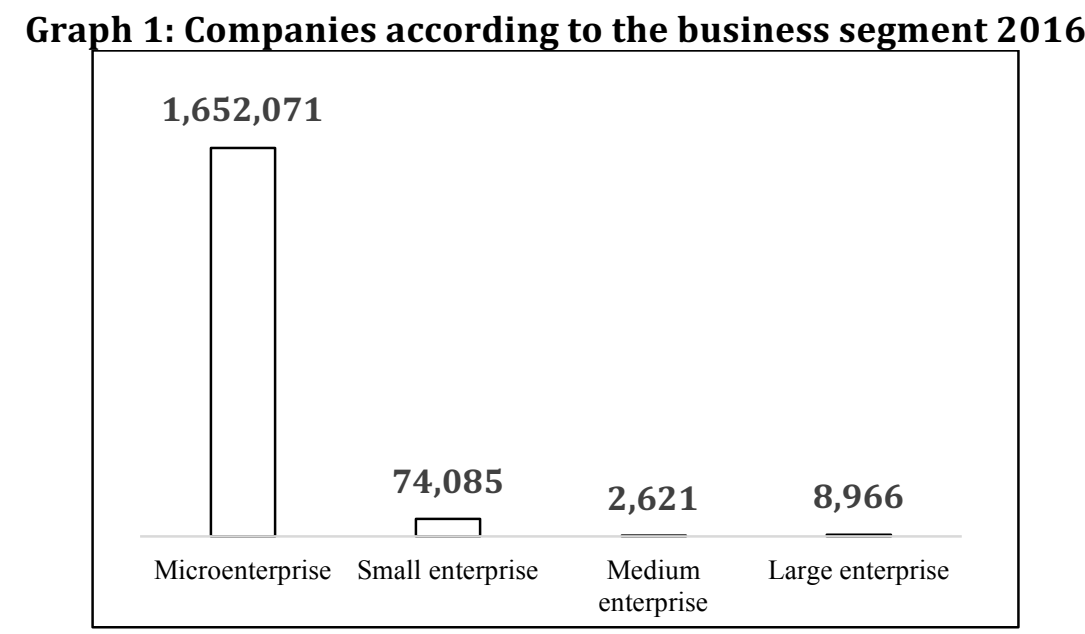

Source: SUNAT, 2016 
The importance of agriculture and mypes in the country's economic sector has been identified by the figures indicated. It is therefore necessary to analyze the relationship between these two sectors and their economic representation at the national level.

Table 1 shows the results obtained by the Ministerio de Producción (2016), where MSEs in the "agriculture, hunting and forestry" sector are formed by a total of 23.908 companies, of which $90.1 \%$ are micro-enterprises, while $7 \%$ are small businesses. In other words, in this agricultural sector, Mypes achieves an approximate share of $98 \%$. Therefore, it is important to carry out an investigation in this business stratum due to the high economic power who have

Table 1: MSEs per stratum 2015

\begin{tabular}{c|lc}
\multicolumn{1}{c}{ Type } & Detail & Total MMSEs \\
\hline$G$ & Wholesale and retail trade & 762,127 \\
$K$ & Real estate, business and rental activities & 228,626 \\
$O$ & Other community service activities & 180,522 \\
$D$ & Manufacturing & 151,584 \\
$I$ & Transport & 137,186 \\
$H$ & Hotels and restaurants & 126,113 \\
$F$ & Construction & 58,093 \\
$N$ & Health services Activities & 24,468 \\
$A$ & Agriculture, livestock hunting and forestry & 23,908 \\
$M$ & Private education & 15,953 \\
$C$ & Mining & 11,562 \\
$J$ & Financial institutions & 3,564 \\
$B$ & Fishing & 3,495 \\
$E$ & Electricity, fishing and water & 1,576
\end{tabular}

Source: SUNAT, 2015.

Graphic 2, elaborated with the data presented by the Ministerio de Agricultura (2015), it is appreciated that, during the period from 2011 to 2015, the total harvested agricultural area has managed to grow by $9.15 \%$, ie, has presented a positive trend of growth. However, it is remarkable the scenario presented by the Cherimoya sector, which shows great stability, which could reflect a problem in the production of this fruit.

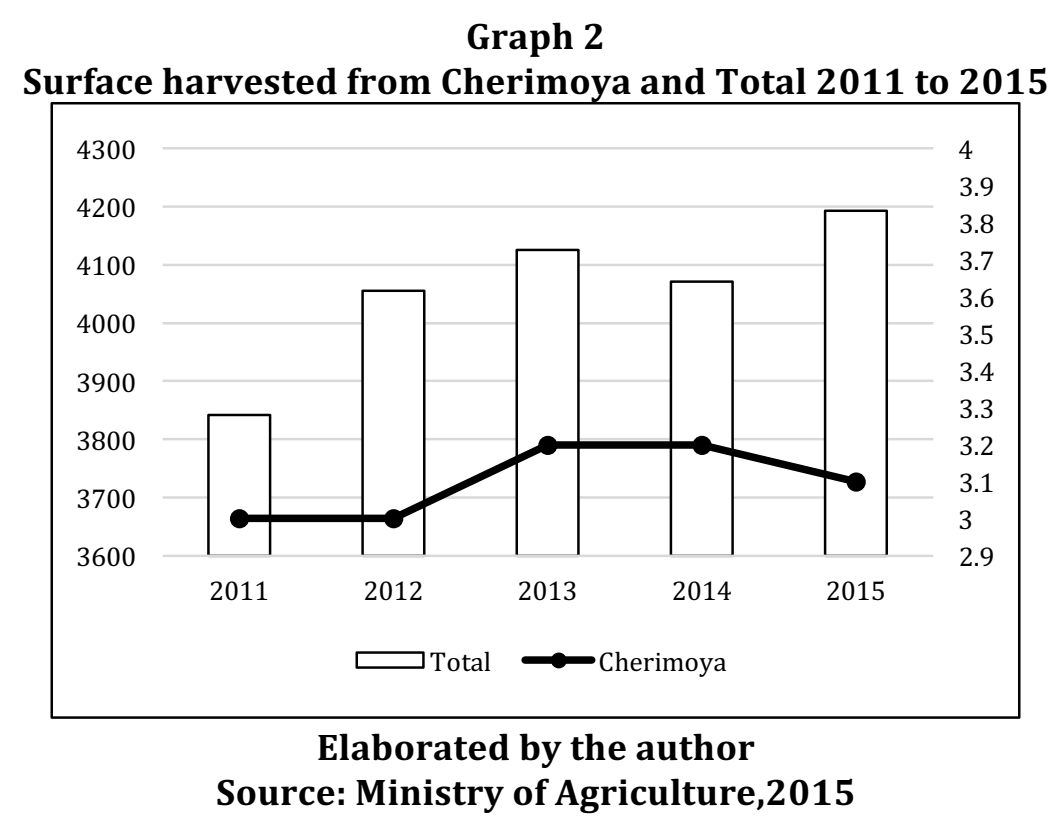


With the graph presented, the production of Cherimoya has remained constant in recent years. In order to obtain a better analysis, the zone with the largest harvest distribution of Cherimoya was defined with the following considerations: Percentage of harvest at departmental level, percentage of harvest at provincial level and percentage of harvest at district level.

It is important to consider that there are 4 major producers of cherimoya in the world: Spain, Peru, Chile and New Zealand. Spain is considered the world's largest producer of this fruit with output ranging from 38000 to 50000 tons per year. The distribution of this production corresponds to $80 \%-90 \%$ to the national market, while $10 \%-20 \%$ is for export market. Which makes a notable difference for Peru as it produces between 20,000 and 25,000 tons and only exports between $1 \%$ and $2 \%$ of this production.

In view of what was raised and according to the data obtained by the Ministry of Agriculture (2015), it is observed in Graphic 2, 42.5\% of the harvest of Cherimoya comes from the department of Lima. Thus, $62.5 \%$ of the harvest belongs to the province of Huarochiri. Finally, in this province it is obtained that $66 \%$ of the harvest, coming from the districts of San Mateo de Otao and Callahuanca. In order to have a greater representativeness of the sector, this research project will focus on the two last districts mentioned.

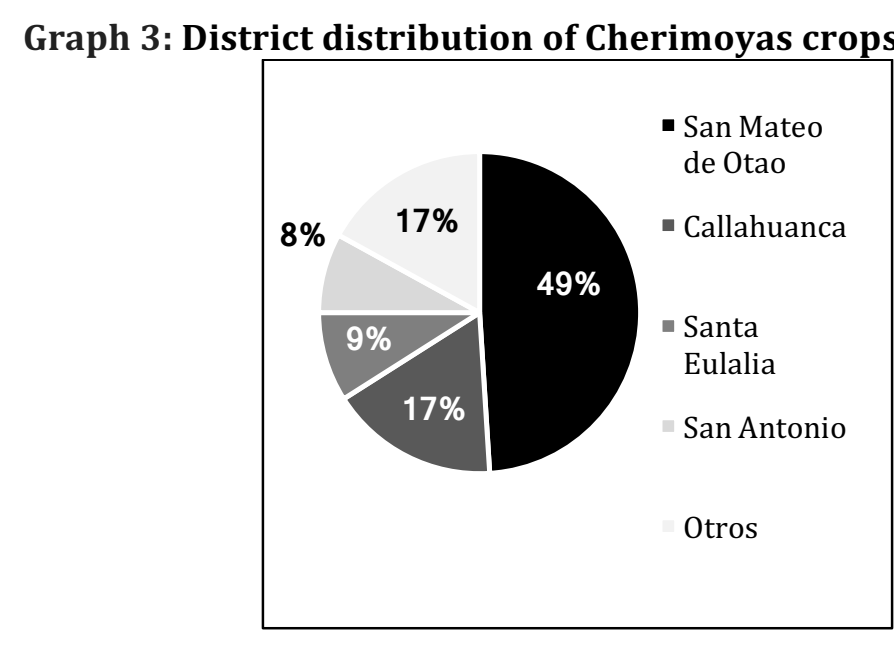

Source: Ministry of Agriculture, 2015.

\section{Instrument development and data collection}

\section{METHODS}

In order to define the research population, the number of farmers in the research area was determined. The number of farmers amounted to 1320 between the two districts, San Mateo de Otao and Callahuanca, according to the report delivered by the municipal secretariat of both districts.

The sample size was defined from the sample size formula for finite populations, as indicated by the author M.H. Badii and others (2008). For the present investigation, it was considered to take the following values to apply them to the formula:

- Population size $(\mathrm{N})=1320$

- Sample error (d): $90 \%$

- Proportion of success (p): 50\%

- Failure rate (q): 50\%

- Value for trust (Z): 1.28 


\section{Figure 1: Formula for sample size

$$
n=\frac{N z^{2} \sigma^{2}}{d^{2}(N-1)+z^{2} \sigma^{2}}
$$

Source: Badii and Other (2008)

The result of the sample determined that the sampling technique chosen in 64 farmers should use to obtain results representative of the sector under study

\section{Snowball Method}

The snowball method was used as the non-probabilistic sampling technique through interviews with numerical questions, closed and open to growers of cherimoyas to perform an effective analysis of the sector.

The interviews lasted between 15 and 25 minutes and were carried out in the farmers' homes or in the places most frequented by the population of both districts: the square and markets.

\section{Sample Characteristics \\ MSE Cherimoya Sector Profile}

This sector does not have a clear definition of the processes. The MSEs dedicated to the cherimoya production are totally isolated and do not have formalized procedures that allow them to be executed. They are totally unpredictable and poorly controlled.

The production of Peruvian cherimoya has remained constant in recent years, however, Spain which is the world leader country in the production of this fruit produces $233 \%$ more tons per hectare compared to Peru. This is reflected in the low annual production of Peru, which represents $43 \%$ of Spanish production. For this reason, it is possible to affirm that there is a problem of low productivity in this sector.

\section{Farmer profile}

Farmers who belong to this sector do not have technical education. Many of them only have school education. They are people who depend totally on the income that the sale of this fruit can give them which are only in harvest months. Therefore, they are not willing to invest in improving their production and risk the little money they have.

\section{RESULTS}

Table 1 shows the details of the 30 results obtained from the interview made to the farmers and how these are linked to the inputs and outputs of the cherimoya sector environment.

It's possible to observe 13 results that affect the input of the sector's environment, such as production planning, production records, the purchases made and the techniques previously used to produce cherimoya.

On the other hand, there are 17 results associated with the output of the environment of the sector under study, which mainly impacts the quality of the product and the maintenance activities of the crop.

Further, based on the results obtained, it was identified that the causes of the problem of the cherimoya sector were associated to 3 critical processes that reflected the unproductiveness of this sector, which are the following: 
- Process of planning management and production control.

- Process of logistics management.

- Process of quality management.

Table 1: Results of the interviews with the cherimoya farmers of San Mateo de Otao and Callahuanca

\begin{tabular}{|c|c|c|c|c|}
\hline No & Result of the interview & Type & Non-productivity & Process \\
\hline 1 & $\begin{array}{l}\text { None produces more than } 10 \text { tons of } \\
\text { production per year, with an } \\
\text { average indicator of } 6-8 \text { tons / } \\
\text { hectare }\end{array}$ & Output & $\begin{array}{l}\text {-Low production, less } \\
\text { amount of chirimoyas to } \\
\text { sell } \\
\text {-Inefficiency in the use of } \\
\text { the land }\end{array}$ & $\begin{array}{l}\text { Planning, Control and } \\
\text { execution of production }\end{array}$ \\
\hline 2 & $\begin{array}{l}40 \% \text { of farmers say they do not } \\
\text { control their processes. The other } \\
60 \% \text { say control by knowing about } \\
\text { them. }\end{array}$ & Input & $\begin{array}{l}\text {-Loss of production due to } \\
\text { lack of control. } \\
\text {-high percentage of low } \\
\text { quality products or } \\
\text { depletion }\end{array}$ & $\begin{array}{l}\text { Planning, Control and } \\
\text { execution of production }\end{array}$ \\
\hline 3 & $\begin{array}{l}40 \% \text { buy what the supplier has, } \\
\text { another } 40 \% \text { buy } 1 \text { time, and the } \\
\text { rest buy more than once a year. }\end{array}$ & Input & $\begin{array}{l}\text { Don't just buy what you } \\
\text { need, increase your costs }\end{array}$ & $\begin{array}{l}\text { Planning, Control and } \\
\text { execution of production }\end{array}$ \\
\hline 4 & $\begin{array}{l}45 \% \text { do know what they need per } \\
\text { tree for talks, } 40 \% \text { for experience } \\
\text { and } 15 \% \text { only use the inputs they } \\
\text { have. }\end{array}$ & Input & $\begin{array}{l}\text { They don't take the } \\
\text { maximum performance } \\
\text { that a tree can have. }\end{array}$ & $\begin{array}{l}\text { Planning } \\
\text { Control and execution } \\
\text { of production }\end{array}$ \\
\hline 5 & $\begin{array}{l}72 \% \text { of farmers do not register their } \\
\text { processes (inputs, dates, quantities } \\
\text { used) }\end{array}$ & Input & $\begin{array}{l}\text { Inefficiency in the use of } \\
\text { resources (MP, inputs, Etc) }\end{array}$ & $\begin{array}{l}\text { Planning, Control and } \\
\text { execution of production }\end{array}$ \\
\hline 6 & $\begin{array}{l}90 \% \text { do not record how much it has } \\
\text { produced per category. }\end{array}$ & Output & $\begin{array}{l}\text {-Does not know which } \\
\text { category is more profitable } \\
\text { to the farmer. } \\
\text {-Loss of earnings by } \\
\text { sweeping sales, not } \\
\text { knowing the quantities by } \\
\text { category } \\
\text {-Cannot know how much it }\end{array}$ & $\begin{array}{l}\text { Planning, Control and } \\
\text { execution of production }\end{array}$ \\
\hline 7 & $\begin{array}{l}48 \% \text { do not have production } \\
\text { records from previous years. }\end{array}$ & Input & $\begin{array}{l}\text { can produce, so it's } \\
\text { impossible plan the need } \\
\text { for resources. }\end{array}$ & $\begin{array}{l}\text { Planning, Control and } \\
\text { execution of production }\end{array}$ \\
\hline 8 & $\begin{array}{l}\text { More than } 80 \% \text { of farmers do not } \\
\text { plan their production }\end{array}$ & Input & $\begin{array}{l}\text {-Loss of production due to } \\
\text { inefficient planning } \\
\text {-Inefficiency in production } \\
\text { times }\end{array}$ & $\begin{array}{l}\text { Planning, Control and } \\
\text { execution of production }\end{array}$ \\
\hline 9 & $\begin{array}{l}\text { No farmer planned how much this } \\
\text { year will produce }\end{array}$ & Input & $\begin{array}{l}\text {-low production due to lack } \\
\text { of inputs. } \\
\text {-Increased costs by not } \\
\text { knowing how much it } \\
\text { requires. }\end{array}$ & $\begin{array}{l}\text { Planning, Control and } \\
\text { execution of production }\end{array}$ \\
\hline 10 & $\begin{array}{l}80 \% \text { defines the number of people } \\
\text { to work according to the size of } \\
\text { their land, the remainder } \\
\text { outsourcing the work by activities. }\end{array}$ & Input & $\begin{array}{l}\text {-Overcosts for excessive } \\
\text { labor. } \\
\text {-Delays in production times }\end{array}$ & $\begin{array}{l}\text { Planning, Control and } \\
\text { execution of production }\end{array}$ \\
\hline 11 & $\begin{array}{l}60 \% \text { do maintenance of their crops } \\
\text { only once a year, } 30 \% \text { do } 2 \text { times } \\
\text { more. }\end{array}$ & Output & $\begin{array}{l}\text {-Low production due to } \\
\text { impairment of land. }\end{array}$ & $\begin{array}{l}\text { Planning, Control and } \\
\text { execution of production }\end{array}$ \\
\hline
\end{tabular}


More than $80 \%$ of growers have wholesalers as the main customers of their fresh harvest.

$90 \%$ of growers do not know the value of Cherimoya in the final market

$100 \%$ of growers sell independently, there is no cooperative or collection center at the district level.

$100 \%$ of the growers who have as main clients the wholesalers stated that these are the ones that put the final price per kilo of Cherimoya.

in an individual way.
No farmer has close relationships with suppliers.

No farmer has close relations with wholesalers.

There is No knowledge of other providers outside the area.

$5 \%$ of farmers are both wholesalers, who buy the Chirimoyas from their colleagues.

The $90 \%$ of farmers collect the fruit of the tree without the beginning of the ripening process (green color to Pale green).

$90 \%$ of farmers do not prune the trees of Cherimoya, which generates that the tree does not withstand the weight of the harvest and the Chirimoyas fall from the tree. $80 \%$ of farmers do not classify their crops by degree of maturity, instead, it allows the wholesaler to do so and place the price by category. Only $40 \%$ has good quality grafting patterns that will allow them to homogenize their production.
Output Lose opportunity to buy a new way of selling

Logistics Management

-Growers do not know the

Output negotiating power they have with their production.

-There is no sale price established by the growers, nor a minimum to offer to the buyers.

-Wholesalers are the ones who decide the final price.

Growers do not receive an adequate profit that allows

Output them to invest and increase their productivity

-The price that farmers pay for their inputs or services is only that requested by their suppliers, without negotiation or discounts for purchases in quantity and/or jointly between several buyers.

Input

-Hinders negotiation and pricing.

-Hinders negotiation and pricing.

Output -Generates loss of opportunity with respect to selling prices.

-Loss of opportunity to get

Input a better price at the time of making purchases.

-it does not allow the development of other farmers.

Output -They take away the opportunity to grow together, and they do it individually.

Output

Immature Cherimoya generates loss of income

Chirimoyas not suitable for sale or consumption

Loss of income due to the quality of the fruit

Input Low quality Chirimoyas
Quality Management

Logistics Management

Logistics Management

Logistics Management

Logistics Management

Logistics Management

Logistics Management

Logistics Management

Logistics Management

Quality Management

Quality Management

Quality Management 
$100 \%$ of farmers do not verify that

25 cherimoyas with wounds have healed before they are offered to their purchaser.

The $95 \%$ does not carry a control (booklet) of the exact date of harvest, which does not allow to control the days of maturity that has the cherimoya so that they can sell them faster.

$75 \%$ does not check that $100 \%$ of its harvest is clean after washing.

$90 \%$ is not free from the pest attacks of the fruit fly, which affects the final product. $60 \%$ of farmers do not invest in treatments to improve the epidermis problems that affect their harvest. $100 \%$ consider that the weight of the Cherimoya is more important than the form of this at the time of selling their production $\begin{array}{ll}\text { Output } & \begin{array}{l}\text { Chirimoyas with wounds } \\ \text { without scarring }\end{array}\end{array}$

Output Cherimoya lifespan Quality Management

Output Chirimoyas with materials on its surface

Quality Management

Output Attack of pests in the fruit Quality Management

Output Chirimoyas with alterations in the epidermis

Quality Management

Output Loss of income

Quality Management

\section{Source: Elaborated by the author}

\section{DISCUSSION OF RESULTS}

To be able to discuss the results, Table 3, indicate the data of the country with the highest productivity of custard apple, Spain. This information is necessary to determine the difference between both countries and to evaluate the productivity of the cherimoya sector in Peru.

Table 3: Productivity comparison between the Spain and Peru

\begin{tabular}{c|ccc} 
Country & $\begin{array}{c}\text { Surface } \\
\text { (ha) }\end{array}$ & $\begin{array}{c}\text { Production } \\
\text { (tn) }\end{array}$ & $\begin{array}{c}\text { Productivity } \\
\text { (tn/ha) }\end{array}$ \\
\hline Spain & 3.1 & 44.1 & 14.3 \\
Peru & 3.7 & 24.8 & 6.7
\end{tabular}

Elaborated by the author

Source: Ministry of Agriculture of Peru, 2016. Source: Statistical Yearbook forward Spain, 2016.

Table 1 shows that, although both countries have a similar number of hectares, Spain has a yield of $233 \%$ more tons per hectare compared to Peru. This is reflected in the low annual production of Peru, which represents $43 \%$ of Spanish production. For this reason, it is possible to affirm that there is a problem of low productivity in this sector and it will be complemented with the analysis of the results of the interviews.

(1) The first result obtained was on the average yield of farmer's crops in San Mateo de Otao And Callahuanca, the producers indicated that they produced about 6 to 8 tons of cherimoya per hectare, which when comparing with the productivity of the crops of the largest producer of this fruit, Spain, evidences the little use of the Cherimoya tree, which can be by factors such as inefficient cultivation techniques, poor maintenance of the crop, poor fertilization of the tree, among others. By having low yield in the crops, the level of production is not enough to be able to satisfy the internal and external demand, which are costs of sale opportunity. 
(2) The interviews carried out gave as one of the results that $40 \%$ of the farmers interviewed do not control in any way their productive processes, either direct processes to the field, direct to their purchases or sales. This generates losses in production due to products that are depleted by quality factors and cannot be given in a good way to the consumption of visitors, as well as the sale of wholesalers.

(3) It is evident that farmers did not control the purchases of their inputs in General, 40\% buys the amounts that the supplier establishes as a sales lot, which makes the farmer dependent and has no control over his purchasing management, this style of purchase can generate on cost for purchases not required, as well purchases by necessity, in both scenarios, monetary losses fall. Another $40 \%$ of the farmers purchase annually, depending on their quantities required in previous crops, which makes their purchase costs less, since they buy at scale and the sale price for higher amounts reduces, being beneficial for the Farmers. The rest of the producers, buy when they require the inputs, can buy more than once a year. Undoubtedly, the purchase management of farmers in general, is not done correctly, which affects the planning of purchases and the cost of inputs, which generates money losses and making the economic results unproductive.

(4) Within the control of the crops is the correct use of inputs towards crops, in the interviews conducted, $45 \%$ of the producers say they learned the requirements of fertilizers, fertilizers, water, among other inputs for the talks In the districts, where they taught to give a good treatment to the Crops to get better production results. However, $40 \%$ of respondents mentioned that with respect to the use of inputs for each tree were amounts they had learned with experience over the years on Cherimoya crops, which makes them empirical producers and not They can maximize the yield of their crops, which leads to a low productivity production.

(5) Recording processes, makes it easy to control executions of activities, costs, production and marketing; Which in turn makes it easier to make a planning plan, to recognize the flow of processes, among others. However, $72 \%$ of the farmers do not register their processes, in which it would help them to know the quantities of resources used, the Times by activity, the productions obtained, the losses generated. Producers failing to register fall into resource use and consumption inefficiencies, which leads to increased production costs.

(6) An important factor for the marketing of Chirimoyas is based on the registration by category of the produced fruit, which depend on the size and shape. The Wholesalers have established purchase prices by category, as it is thus their way of buying, but also, they have the mode of purchase when sweeping, which makes reference, when buying the total production of a farmer no matter the category that At a fixed price, this modality is generally given when the farmer does not have a record of his production per category and $90 \%$ of the farmers interviewed do not register that way, which causes them to sell when sweeping and not be able to have a profitability Correct for its production.

(7) An important and basic point to register on the part of farmers is the production of previous years; In spite of this, $48 \%$ of the producers have no record of the productions of previous years. By not having to register their productions, they cannot get to know their production capacity, nor plan the resource requirements to be used; Therefore, it cannot identify the way in which production costs can be reduced, let alone create commercial relations with wholesalers or transformers of the fruit, since it does not have a solid knowledge of its previous productions and cannot Offer quantities to offer.

(8) Then to make themselves known that the behavior of the farmers of San Mateo of Otao And Callahuanca is not to register or control their processes, another point to consider is that $80 \%$ of respondents do not make a production planning to obtain annually or by harvest, is thus What They lose production level by not planning the time of the 
productive processes and the resources to be used. While it is true that there are $20 \%$ of the producers that if they plan, their way of planning is inefficient and that is reflected in the yields of their crops. The problem of low productivity in the chirimoyas producing sector of these districts is based on its little or almost zero planning of its production.

(9) Within the non-planning of the farmers, one point to consider that in the totality of the interviewees did not plan the production to have at the end of each harvest or yearly, which represents a lack of knowledge in the requirements of resources to Use in their crops can cause a shortage or oversupply of resources over the period of cultivation, both scenarios fall in the rise of production costs, so it is affected the final productivity in the Farmers either by factors of production or profitability.

(10) Labor to require in the process of Production Whether in the activities As a harvest, pruning, maintaining, among others, influences the amount of personnel to use and the quality of labor. The interviews resulted in $80 \%$ of selected farmers defining the number of staff to use for production activities; While the rest outsourced the activities to be done. Producers who define the amount of hand Work They do so empirically with quantities already used in previous years and are based on the extension of the crops to work, this type of resource designation is inaccurate and inefficient that Leads to over costing problems due to excessive labor and high times of

(11) The $60 \%$ only performs an annual maintenance of the crops, which is a bad practice, because it does not give the necessary care to the trees of Cherimoya. The low performance obtained by this bad practice is due to the loss of production opportunity and the Losses generated either by the fall of the fruit in an early time to harvest or by excessive harvest time. However, there are $30 \%$ of the producers interviewed who do 2 to more times a maintenance to farmland, who have better results compared to those who only perform an annual maintenance. Finally, $10 \%$ of farmers do not maintain their crops, they are those whose yields are very low, about 3 to 4 tons of chirimoyas per hectare.

(12) Farmers sell their products in different ways (ice cream, pisco, etc.). The main form of presentation is the fresh Cherimoya, which is sold directly to wholesalers. More than $80 \%$ of the growers sell exclusively to these their fresh harvest, the remainder transforms the fruit into a finished product for the final customer bandage (ice cream, drinks, jam, yogurt, etc.). Farmers have the possibility to innovate and sell their products in different ways to generate greater profits. However, being a large percentage that sells its harvest only to wholesalers, there is a great dependence on these and you miss the opportunity to get a new way of selling.

(13) Most growers do not know the price of Cherimoya in the final market; That is, they are not informed about the profit that intermediaries obtain along the chain or the final sellers. This harms them in the sense that they do not know the true negotiating power they could have with wholesalers by selling their Product. In addition, it favors the wholesalers to ask for the price they want, taking advantage of the ignorance of the farmers.

(14) All the farmers interviewed sell their production independently to each wholesaler. This favors the wholesalers to take advantage of these buying the Cherimoya at different prices, generating a loss for the farmer. Farmers in this case have no negotiating power because they sell separately and many are unaware of the price of Cherimoya in the final market. If a cooperative were formed, it would be the growers who could put the selling price or a base price to negotiate, increasing the amount sold and their earnings at the same time. 
(15) All farmers who sell their crops directly to wholesalers claim that these are the ones that put the final price per kilo of Cherimoya. Because farmers only want to sell all their production, they have no choice but to accept the price offered by the wholesaler, thus generating uncontrolled losses or false profits. In some cases, they think they are winning when they are actually losing. This generates that acquire only enough to survive, without being able to invest in its production, innovate and increase its productivity.

(16) Wholesalers only see farmers as people from whom they get a product to be able to sell later, farmers see it the same way. There is No close relationship or any attempt at negotiation or agreement to obtain mutual benefits. This is detrimental to the negotiations of the moment and subsequent fixation of a selling price that may benefit both parties. Then it generates a loss of opportunity to improve the sale price of the Cherimoya and increase the profit of the farmers, as well as to improve the level of service that is given to the customers by the Cherimoya sector in the districts.

(17) All the farmers do their purchases individually, there is no agreement between them or any board in which they agree to buy together the inputs. This prevents favorable conditions so that they can negotiate with their suppliers the possibility of making purchases in large quantities and generate a greater margin of profit. In addition, these conditions would also allow farmers to buy their inputs at a better price and have a cost savings of inputs.

(18) Farmers do not know their suppliers, they simply have a seller-buyer relationship. This makes it difficult to negotiate and, in turn, the pricing that results in the increase in costs within the chain. Not being able to have an agreement with the supplier and engaging in a favorable negotiation for both parties prevents the overall costs of the sector's supply chain from being reduced.

(19) Farmers only know their primary provider; That is to say, those who go to the same districts or the few who know in Chosica, where some growers travel on weekends to do their shopping. They have No knowledge of others who may sell inputs or materials to a better Price or better quality. So there is a loss of opportunity to lower your costs and get a better price.

(20) This minority of farmers, who are also wholesalers, know the reality of the crops and take away the opportunity for smaller farmers or with less productivity to be able to progress or learn new ways of managing their business. They buy their production at a reduced price to generate a greater profit for themselves by taking advantage of the ignorance of others.

(21) There is a productivity problem, because the harvested Cherimoya does not have the minimum quality characteristics for sale to the public. This is explained because $90 \%$ of farmers do not perform the necessary pruning technique during the first years of the Cherimoya tree. As a result, the Chirimoyas fall from the trees and generate a loss of production and that these are not suitable for sale and, therefore, for consumption. This result is related to the sub-process of preventive maintenance of the crop, since pruning is part of the maintenance of this fruit.

(22) $40 \%$ do not have adequate patterns that allow them to produce chirimoyas of good quality, which is a wasted that generates unproductivity by not performing the grafts that produce a better crop that is reflected through a higher yield of the tree and High quality fruits. As a result, the production of chirimoyas of these farmers is of low quality, which impacts on the sale price demanded by the wholesaler. This result is linked to the sub process of agricultural techniques, therefore, the graft is a technique to improve the quality of the crops

(23) Within the outputs of the quality management process, indicates that $90 \%$ of farmers collect the fruit without it has a pale green hue. This generates unproductivity, 
because the extracted chirimoyas are immature or blackened, which results in a loss of product. The thread related to this result is that of agricultural techniques, since it requires an improvement in the technique to be used during the harvesting.

(24) $80 \%$ of the farmers do not classify their production by degree of maturity, instead, it allows their buyer to make this classification. Therefore, the price per category is defined by the wholesaler generating loss of income due to the inadequate price variation in terms of the quality of the product. This result is associated with the agricultural technical sub-process because the farmer needs to know the correct classification of Chirimoyas by size according to the national standard and the price to be demanded for each rank.

(25) None of the farmers check that the wounds of the Chirimoyas have healed before offering them to their buyer. As a result, the Chirimoyas lose their quality and the buyer has the benefit of paying a lower price for them. This result is linked to the quality control thread, as the farmer does not check that the product complies with the minimum quality requirements according to the Peruvian standard.

(26) $95 \%$ of farmers do not control the exact date of harvest, which prevents them from taking control of the days of maturity and can be sold at the right time, which generates unproductivity of this process. This result is connected to the production log thread, as it is necessary to keep a manual record on harvest dates to avoid losing sales due to product quality.

(27) $75 \%$ of the farmers interviewed does not ensure that all their crops are clean and consequently suitable for the sale and consumption of the public, generating unproductivity in the quality process. In turn, this result is directly associated with the quality control thread, which will help the fruit meet the minimum quality standards.

(28) $90 \%$ of farmers interviewed do not have their crops free from the attacks of the fruit fly plague, which leads to infect the fruits with this plague. Therefore, this result is linked to the sub-process of agricultural techniques, which will allow the farmer to apply the appropriate techniques to combat this type of pests and so the quality of the Cherimoya is not affected.

(29) $60 \%$ of the farmers interviewed are not willing to invest in treatments for epidermis problems that suffer their crops. This means that the fruit suffers alterations in their skin and that the buyer demands a less sale price for these chirimoyas.

Therefore, this result is linked to the subprocess of preventive maintenance of the crop, which will focus on the procedures prior to follow to avoid malformations in cherimoya crops.

(30) $100 \%$ of farmers interviewed considers that the weight of the Cherimoya is more important than the form it may have, because they assume that the larger they can ask for a higher price for their products. However, it has not been considered that within what is required by the Peruvian standard of quality of Cherimoya requests to meet the requirements of form and texture of this fruit in order to be sold. For this reason, this result is associated with the quality Control thread, as it will allow the farmer to consider the minimum quality requirements of the Cherimoya before he can offer it to his final purchasers.

According to the presented diagnosis, it is sustained that the cherimoya sector presents a productivity problem. These non-productivities are related to three critical processes: Management of Planning and Production Control, Logistics Management and Quality Management 


\section{CONCLUSIONS AND FUTURE RESEARCH}

This research suggests two main findings. First, the application of the snowball method was key to discover the opportunities of the cherimoya sector. Second, the definition of three critical processes that would allow improving the productivity of the sector.

\section{Snowball Method}

The sector study required depth analysis to understand why productivity was low compared to Spain. For this, it was necessary to understand which sampling method was the appropriate one to carry out the diagnosis in the cherimoya sector. To this end, I had to research the type of profile MSEs and local farmer. This indicated that they were undeveloped mypes and that a large part of them worked independently. In addition, farmers had only primary education, so many of them had no idea how to improve their production.

Based on this information, it was determined that the diagnosis would be made by snowball sampling because it allowed in-depth interviews with numerical questions, closed and open to producers of custard apples to perform an effective analysis of the sector. This allowed us to conclude with 30 results that pointed to the non-productivity of the sector.

\section{Critical process}

The responses from the snowball sampling covered several factors that affected productivity: cultivation methodology, planning, care of the fruit, suppliers. From the results, 3 critical processes were found that were required to improve the productivity of the sector: process of planning management and production control, process of logistics management and process of quality management.

\section{Process of planning management:}

It was identified as a critical process, which is in the results, show a low production. This premise is related to the lack of controls. In addition, there is an inefficiency in the use of land, so you cannot know how much it can produce, so it is impossible to plan the need for resources.

\section{Process of logistic management:}

In showing of the results of the interviews, this process was identified as critical, as the producers do not know the negotiating power they have with their production, therefore it is difficult for them establish the prices to its fruit. By the way, they loss of opportunities with respect to selling prices. In addition, there is an opportunity to get a better price at the time of making purchases.

\section{Process of quality management:}

It is considered a critical process because farmers did not control the quality of the fruit throughout the production cycle, even when it was going to be sold. When consulting with the various farmers, it was evident that each one had different agricultural techniques which reflected the varied quality of cherimoya among all the interviewees. In addition, they considered that the cherimoya of better quality was the largest, when it is the opposite because the current demand requires smaller sizes. This process needs to cover the entire productive cycle from the preparation of the land to the pre-sale of the fruit in a way that ensures the quality standards demanded by consumers.

\section{References}

ATYA NUR AISHA AND OTHERS (2016) Developing Institutional Model for Association of Agricultural SMEs. Advanced Science Letters, Volume 22. Recovered from: https://doi.org/10.1166/asl.2016.7037 
Sotelo, F., Molina, A., \& Rojas, K. (2018). Application of the Snowball Sample in the diagnostic based on factors that affect the productivity of Cherimoya production in MSEs: A case of study of Callahuanca and San Mateo de Otao, Peru. Advances in Social Sciences Research Journal, 5(8) 5471.

CANAVIRE-BACARREZA, GUSTAVO AND ROBLES, MARCOS (2017) Non-parametric analysis of poverty duration using repeated cross section: an application for Peru. Applied Economics. Recovered from: http://www.inesad.edu.bo/bcde2013/papers/BCDE2013-50.pdf

DIARIO GESTIÓN (2014) Gestión te explica: ¿Qué es y cómo se calcula el PBI? Recovered from: http://gestion.pe/opinion/gestion-te-explica-que-y-como-se-calcula-pbi-2095156

DIARIO GESTIÓN (2017) El Niño Costero y las cifras “muy dramáticas” de la destrucción que ocasionó en Perú. Recovered from http://gestion.pe/eco(nomia/nino-costero-y-cifras-muy-dramaticas-destruccion-que-ocasionoperu-2186591

ESHETU AND KETEMA (2013) Economic Impact of Support Service Program on Micro and Small Enterprises: The Case of Dire Dawa Administration, Ethiopia. Agris On-line Papers in Economics and Informatics Recovered from: https://www.researchgate.net/publication/263811472_Economic_Impact_of_Support_Service_Program_on_Micr o_and_Small_Enterprises_The_Case_of_Dire_Dawa_Administration_Ethiopia

GARG, SONU AND AGARWAL, PARUL (2017) Micro, Small and Medium Enterprises in India: A Review of Growth and Challenges in the Present Scenario. International Journal of Applied Business and Economic Research (Serials Publications). Recuperado por:

https://www.researchgate.net/publication/316009384_Micro_small_and_medium_enterprises_in_India_A_review of_growth_and_challenges_in_the_present_scenario

GAZI SALAH UDDIN, MUHAMMAD SHAHBAZ, MOHAMED AROURI, FRÉDERIC TEULON (2017) Financial development and poverty reduction nexus: A cointegration and causality analysis in Bangladesh. ELSEVIER. Recovered from: https://sci-hub.io/https://doi.org/10.1016/j.econmod.2013.09.049

GAZI SALAH UDDIN, MUHAMMAD SHAHBAZ, MOHAMED AROURI, FRÉDERIC TEULON (2017) Financial development and poverty reduction nexus: A cointegration and causality analysis in Bangladesh. ELSEVIER. Recovered from: https://sci-hub.io/https://doi.org/10.1016/j.econmod.2013.09.049

GIVEN, LISA (2008) Qualitative Research Methods. Editorial: Board. United Kingdom. Recovered from: http://www.yanchukvladimir.com/docs/Library/Sage\%20Encyclopedia\%20of\%20Qualitative $\% 20$ Research\%20 Methods-\%202008.pdf

GOEDELE VAN DEN BROECK AND MIET MAERTENS (2017) Moving Up or Moving Out? Insights into Rural Development and Poverty Reduction in Senegal. ELSEVIER. Recovered from:

http://www.sciencedirect.com/science/article/pii/S0305750X15311475

HAFTOM HAILE ABAY AND OTHERS (2014) External Factors Affecting the Growth of Micro and Small Enterprises (MSEs) in Ethiopia: A Case Study in Shire Indasselassie Town, Tigray. Eurpean Journal of Business and Management. Recovered from: http://www.iiste.org/Journals/index.php/EJBM/article/view/17147

INSTITUTO NACIONAL DE ESTADÍSTICA E INFORMÁTICA (2017) Producto Bruto Interno Trimestral. Lima: INEI. Recovered from https://www.inei.gob.pe/media/MenuRecursivo/boletines/02-informe-tecnico-n02_productobruto-interno-trimestral-2017i.pdf

JAROSLAV BELÁS (2015) Risk perception differences between micro-, small and medium enterprises. Journal of International Studies. Recovered from http://www.jois.eu/files/02_Belas.pdf

JOHN W. MELLORA AND SOHAIL J. MALIKB (2016) The Impact of Growth in Small Commercial Farm Productivity on Rural Poverty Reduction. World Development, Vol 91. Recovered from: https://www.sciencedirect.com/science/article/pii/S0305750X16302698

JURGEN, ANTONY Y OTROS (2017) Productive and harmful entrepreneurship in a knowledge economy. Small Business Economics. Recovered from: https://link.springer.com/article/10.1007/s11187-016-9822-x

KOPELKO, MAGDALENA Y ABBOTT, MALCOM (2017) Productivity Growth and Business Cycles: Case Study of Spanish Construction Industry. Journal of Construction Engineering \& Management. Recovered from https://www.researchgate.net/publication/310764434_Productivity_Growth_and_Business_Cycles_Case_Study_o f_the_Spanish_Construction_Industry

MARCOS IVANIC AND WILL MARTIN (2017) Implications of Higher Global Food Prices for Poverty in Low-Income Countries. Agriculture Economics. Recovered from: DOI: 10.1111/j.1574-0862.2008.00347.x

M.H. BADII AND OTHERS (2008) Tamaño óptimo de la muestra. Innovaciones de Negocio. Recovered from: http://www.web.facpya.uanl.mx/rev in/revistas/5.1/a5.pdf 
MELLORA, JOHN Y SOHAIL J.MALIKB (2016) The Impact of Growth in Small Commercial Farm Productivity on Rural Poverty Reduction. World Development. Recovered from: http://www.sciencedirect.com/science/article/pii/S0305750X16302698

MINISTERIO DE AGRICULTURA (2015) Calendario de siembras y cosechas. Lima: Minagri. Recovered from: http://siea.minag.gob.pe/calendario/

MINISTERIO DE AGRICULTURA (2016) Anuario Estadístico de la Producción Agrícola y Ganadera 2015. Lima: Minagri. Recovered from

http://siea.minagri.gob.pe/siea/sites/default/files/anuario_produccion_agricola_ganadera2015.pdf

MINISTERIO DE LA PRODUCCIÓN (2015) Anuario Estadístico Industrial, Mypyme y Comercio Interno. Lima: PRODUCE. Recovered from: http://www.produce.gob.pe/documentos/estadisticas/anuarios/anuario-estadisticomype-2015.pdf)

MORLEY, SAMUEL (2017) Changes in rural poverty in Peru' 2004-2012. Latin American Economic Review. Recovered from: http://www.emeraldinsight.com/doi/abs/10.1108/SSBED-12-2015-

0169?mobileUi=0\&journalCode=jsbed

MUHAMMAD MAHBOOB ALI AND OTHERS (2017) Comparative positioning of small and medium enterprises in Bangladesh, Thailand and Philippines. Economy of Region, Vol 1. Recovered from:

https://econpapers.repec.org/article/uraecregj/v_3a1_3ay_3a2017_3ai_3a2_3ap_3a381-395.htm

OISÍN TANSEY (2007), Process Tracing and Elite Interviewing: A Case for Non-probability Sampling. PS: Political Science \& Politics, 40(4), 765-772. Recovered from: doi:10.1017/S1049096507071211

PURCELL, STEVEN W. Y OTROS (2016) Multiple Factors Affect Socioeconomics and Wellbeing of Artisanal Sea Cucumber Fishers. Plos One. Recovered from:

http://journals.plos.org/plosone/article?id=10.1371/journal.pone.0165633

SATIS DEVKOTA \& MUKTI UPADHYAY (2013) Agricultural Productivity and Poverty Reduction in Nepal. Review of Development Economics, Wiley Blackwell, vol. 17. Recovered from: https://doi.org/10.1111/rode.12062

SAVLOVSCHI, LUDOVICA IOANA \& RALUCA ROBU, NICOLETA (2011) The Role of MSEs in Modern Economy. Economia. Seria Management, 2011, vol. 14. Recovered from: http://ijecm.co.uk/wpcontent/uploads/2015/05/3587.pdf

SUPERINTENDENCIA NACIONAL DE ADUANAS Y DE ADMINISTRACIÓN TRIBUTARIA (2017) Definición de la micro y pequeña empresa. Lima: SUNAT. Recovered from: http://www.sunat.gob.pe/orientacion/mypes/definemicroPequenaEmpresa.html

SYVERSON, CHAD (2017) Does mismeasurement explain low productivity growth? Business Economics. Recovered from:

https://www.researchgate.net/publication/310764434_Productivity_Growth_and_Business_Cycles_Case_Study_o f_the_Spanish_Construction_Industry

THI HONG VAN HOANG Y OTROS (2018) Do crises impact capital structure? A study of French micro-enterprises. Springer. Recovered from: https://link.springer.com/article/10.1007/s11187-017-9899-x

YTER VALLEJO (2008) Forma de hacer un diagnóstico en la investigación científica. TEORÍA Y PRAXIS INVESTIGATIVA, Volumen 3 - No. 2 Perspectiva holística. Recovered from:

https://dialnet.unirioja.es/descarga/articulo/3700944.pdf 